\title{
PENGARUH BUDAYA ORGANISASI TERHADAP KINERJA KARYAWAN (Studi Kasus pada KSU Tabungan Nasional, Singaraja)
}

\author{
Made Ary Meitriana, M.Rudi Irwansyah \\ Jurusan Pendidikan Ekonomi \\ Universitas Pendidikan Ganesha \\ Singaraja, Indonesia
}

e-mail: ary.meitriana80@gmail.com, rudi.irwansyah@undiksha.ac.id

\begin{abstract}
Abstrak
Penelitian ini bertujuan untuk mengetahui pengaruh budaya organisasi terhadap kinerja karyawan pada Koperasi Serba Usaha Tabungan Nasional Singaraja. Penelitian ini merupakan penelitian kausal dimana populasi dalam penelitian ini adalah seluruh karyawan dalam Koperasi Serba Usaha Tabungan Nasional Singaraja yang berjumlah 31 karyawan, di mana keseluruhan populasi dijadikan sebagai sampel penelitian karena jumlah dari populasi kurang dari 100. Data yang digunakan adalah data primer dan data sekunder dimana teknik pengumpulan data menggunakan koesioner dan pedoman wawancara. Hasil analisis menunjukkan bahwa variabel Budaya Organisasi $(\mathrm{X})$ mempunyai pengaruh yang cukup signifikan terhadap variabel kinerja karyawan dengan nilai signifikan sebesar 0,000 (pada tingkat kesalahan $5 \%$ ), sehingga dapat disimpulkan bahwa Budaya Organisasi $(X)$ mempunyai pengaruh yang signifkan terhadap Kinerja Karyawan $(\mathrm{Y})$ pada Koperasi Serba Usaha Tabungan Nasional Singaraja.
\end{abstract}

Kata kunci: Budaya organisasi, kinerja karyawan

\begin{abstract}
This research aims to determine the influence of organizational culture on the performance of employees in Singaraja National Savings Multipurpose Cooperative. This research is a causal research where the population in this study are all employees in the Singaraja National Savings Multipurpose Cooperative, amounting to 31 employees, in which the entire population is used as a research sample because the number of the population is less than 100 . The data used are priprimary data and secondary data where data collection techniques use questionnaires and interview guidelines. The analysis shows that the Organizational Culture $(X)$ variable has a significant influence on employee performance variables with a significant value of 0.000 (at a $5 \%$ error rate), so it can be concluded that Organizational Culture (X) has a significant influence on Employee Performance $(Y)$ at Singaraja National Savings Multipurpose Cooperative.
\end{abstract}

Keywords: Organizational culture, employee performance

\section{PENDAHULUAN}

Seiring dengan berjalannya waktu banyak sekali koperasi yang tumbuh dan berkembang ditengah-tengah kehidupan masyarakat Indonesia. Berdasarkan data Koperasi dan Usaha Kecil Menengah (UMK) keberadaan koperasi di Indonesia sebagai lembaga ekonomi rakyat sudah ada sejak 50 tahun yang lalu, namun uniknya kualitas perkembangannya selalu menjadi bahan perdebatan karena belum mampu berkontribusi banyak terhadap PDB ( Produk Domestik Bruto). Walaupun demikian koperasi telah mampu mengentaskan kemiskinan, dan ikut serta 
dalam mengurangi jumlah pengangguran di Indonesia.

Dalam mendorong berkembangnya suatu perusahaan dan meningkatkan kualitas suatu perusahaan maka harus ada pengelolaan sumber daya manusia (karyawan yang baik). Untuk meningkatkan kinerja karyawan dapat dilakukan dengan menciptakan budaya organisasi yang kuat untuk membentuk sikap dan pola pikir karyawan dalam menyelesaikan tugas-tugas yang dibebankan.

Budaya adalah gabungan kompleks dari asumsi, tingkah laku, cerita, mitos, metafora dan berbagai ide lain yang menjadi satu untuk menentukan apa arti menjadi anggota masyarakat tertentu. Budaya tidak hanya menjadi konsep yang penting untuk memahami masyarakat atau kelompok manusia tetapi juga untuk memahami organisasi.

Budaya organisasi adalah konsep yang marak berkembang dalam satu dasawarsa ini dan akan terus berevolusi. Menurut Wibowo (2010) budaya organisasi dapat mempengaruhi kontribusi secara langsung pada kinerja karyawan dalam menyelesaikan tugas-tugas yang telah dibebankan.Setiap organisasi memiliiki definisi yang berbeda-beda mengenai budaya organisasi. Menurut Robbins (2002) budaya organisasi adalah falsafah, ideologi, nilai-nilai, anggapan-anggapan, keyakinan, harapan, sikap, dan normanorma yang dimiliki secara bersama serta mengikat dalam komunitas atau organisasi tertentu. Adapun dalam budaya organisasi memiliki karakteristik yakni inovasi dan pengambilan resiko, perhatian pada detail, orientasi hasil, orientasi manusia, orientasi tim, agresivitas, stabilitas. Apabila karyawan memiliki karakteristikkarakteristik tersebut maka organisasi atau perusahaan akan menjadi lebih berkembang.

Budaya organisasi dapat memberikan pengaruh positif yang kuat terhadap induvidual yaitu karyawan terutama dalam lingkungan yang bersaing, maka budaya itu akan cepat dalam menghadapi pesaing dan pelanggannya. Bila organisasi tidak memiliki budaya organisasi, anggota yang terdapat didalamnya akan merasa sulit untuk memahami apa yang terkandung dalam organisasi dan pencapaian tujuan tidak berhasil. Menurut Gibson (2002) pegawai atau karyawan sebagai penggerak operasi organisasi, jika kinerja pegawai baik, maka kinerja organisasi juga akan meningkat. Banyak variabel yang mempengaruhi kinerja pegawai salah satunya budaya organisasi. Budaya organisasi sebagai persepsi umum yang dimiliki oleh seluruh anggota organisasi, sehingga setiap pegawai yang menjadi anggota organisasi akan mempunyai nilai, keyakinan dan perilaku sesuai dengan organisasi.

Dengan demikian budaya organisasi menjadikan anggota organisasi fokus kepada pencapaian tujuan organisasi. Kondisi pencapaian tujuan organisasi ini pastinya menciptakan kondisi organisasi ataupun perusahaan yang sehat, sehingga kondisi tersebut dapat menciptakan kinerja karyawan yang maksimal. Menurut Tika (2006) jenis-jenis budaya organisasi berdasarkan proses informasi (1)Budaya rasional, dalam budaya ini proses informasi individual (klarifikasi sasaran pertimbangan logika, perangkat pengarahan) diasumsikan sebagai sarana bagi tujuan kinerja yang ditunjukkan (efisiensi, produktivitas, dan keuntungan atau dampak), (2)Budaya ideologis, dalam budaya ini pemrosesan informasi intuitif (dari pengetahuan yang dalam, pendapat dan inovasi) diasumsikan sebagai sarana bagi tujuan revitalisasi (dukungan dari luar, perolehan sumber daya dan pertumbuhan), (3)Budaya consensus, dalam budaya ini pemrosesan informasi kolektif (diskusi, partisipasi, dan consensus) diasumsikan untuk menjadi sarana bagi tujuan kohesi (iklim, moral, dan kerja sama kelompok), (4)Budaya hierarkis, dalam budaya hierarkis pemrosesan informasi formal (dokumentasi, komputasi, danevaluasi) diasumsikan sebagai sarana bagi tujuan kesinambungan (stabilitas, control,dan koordinasi). Budaya yang baik untuk diterapkan menurut peneliti yaitu budaya consensus dimana dengan kinerja yang berbasis pada kerjasama antar karyawan untuk menyelesaikan masalah dalam organisasi atau perusahaan untuk 
mencapai tujuan organisasi. Segala masalah yang dihadapi perusahaan akan tetap bertahan dengan kerjasama karyawan yang kuat untuk saling membantu antar karyawan sehingga segala menjadi tanggung jawab bersama.

\section{Dalam suatu perusahaan}

diperlukan adanya budaya organisasi yang kuat agar nilai-nilai yang ada dapat benarbenar dipahami dan diterapkan secara mendalam, dianut dan diperjuangkan oleh para karyawan agar dapat tercapai kinerja yang baik dan optimal. Budaya organisasi dapat mempengaruhi cara orang berprilaku dan harus menjadi acuan dalam setiap menyelesaikan tugas-tugasnya dan kebijakan yang diambil. Oleh karena itu budaya organisasi yang terbentuk sangat berpengaruh dengan cara pikir para karyawan dalam menyelesaikan suatu masalah dan dalam hal pengambilan keputusan.

Dalam kasus dari penelitian sebelumnya yaitu penelitian Darmawan (2015), pada Koperasi Simpan Pinjam (KSP) Mellenium Artha Niaga merupakan perusahaan yang memberikan pelayanan pinjaman, kredit kendaraan bermotor, dan tabungan. Budaya organisasi pada KSP digunakan sebagai budaya perusahaan yang berbasis kinerja karyawan sehingga karyawan dituntut untuk memahami dan menerapkan budaya. KSP milan menekankan kepada seluruh karyawan untuk berinovasi dalam bekerja demi kemajuan perusahaan, KSP Milan menenerapkan sistem reward pada karyawan yang berhasil menyelesaikan permasalahan internal perusahaan. Dalam satu bulan sekali diadakan rapat untuk mengetahui permasalahan internal maupun eksternal perusahaan. KSP Milan dalam mengambil suatu keputusan dari permasalahan, tidak semata-mata wewenang suatu pimpinan, tetapi berdasarkan rapat dari komite pimpinan. Dalam kinerja, KSP Milan dibentuk devisidevisi yang menangani permasalahan, seperti devisi kredit, kredit operasional, kredit pinjaman atau analisa.

Budaya organisasi pada KSP Milan dipegang kuat dan dilaksanakan sampai sekarang sebagai sistem makna bersama seluruh karyawan dalam mengarahkan perilaku ke arah yang sama untuk pencapaian visi dan misi perusahaan KSP Milan. Sistem makna tersebut merupakan budaya yang dikembangkan dari segala aspek organisasi yang akhirnya menciptakan komitmen, atau keputusan keluar dari perusahaan bagi karyawan yang tidak mau menerima budaya organisasi yang diyakini bersama.

Berdasarkan

penelitian sebelumnya pada KSP Milan, budaya yang terdapat pada KSP Milan tidak seluruhnya dipahami oleh seluruh karyawan. Dengan lemahnya budaya organisasi yang dipahami mengakibatkan rendahnya tingkat kinerja karyawan, kinerja koperasi dalam arti sejauh mana pengelola harus bekerja sama dengan baik. Dalam kegiatan sehari-hari yang ada pada koperasi yaitu harus bekerja secara tim demi mencapai tujuan perusahaan. Maka dari itu pimpinan perlu menekankan pentingnya budaya yang dianut KSP Milan pada semua lapisan karyawan KSP Milan, sehingga dapat bekerja dengan maksimal. Peranan budaya organisasi yang cukup tinggi penting dalam proses pencapaian visi dan misi KSP Milan, salah satu pengaruhnya adalah terhadap kinerja karyawan.

Pada penelitian Kurniawan (2017) melakukan penelitian pada KSP KOPDA Belitang, berdasarkan hasil penelitiannya budaya organisasi berpengaruh positif dan signifikan terhadap kinerja karyawan KSP KOPDA Belitang, hal tersebut didukung dengan hasil wawancara penelitian sebelumnya pada tahun 2015 merupakan tahun yang kurang menguntungkan bagi Koperasi dan UMKM, namun demikian KSP KOPDA dapat menunjukkan bukti keberhasilan kinerjanya selama satu tahun, KSP KOPDA tetap tumbuh dan berkembang meskipun hidup dalam terpaan krisis ekonomi yang berkepanjangan dan tanpa keberpihakan dari Pemerintah pada koperasi dan UMKM. Hal ini menunjukkan KSP KOPDA memiliki budaya organisasi kuat yang diterima dan diterapkan oleh karyawannya, sehingga rasa kerjasama karyawan dalam menyelesaikan masalah cukup erat.

Pada penelitian Octaviana (2011) melakukan penelitian pada PT. Mirota 
yang merupakan perusahaan pembuatan minuman, roti dan tart. Mirota Kampus dalam menjalankan kegiatannya tidak terlepas dari berbagai masalah. Diprediksikan karyawan memilih hal ini, kemungkinan yang terjadi dikarenakan penurunan kinerja disebabkan motivasi karyawan juga mengalami penurunan. Penurunan ini mempunyai dampak negatif bagi perusahaan. Hal ini dapat dilihat dengan seringnya karyawan datang terlambat, di samping itu, karyawan juga sering mempunyai ide - ide baru yang inovatif tetapi tanggapan dari manajer tidak sesuai dengan yang diharapkan karyawan, karena pihak manajemen dirasa kurang memperhatikan aspirasi karyawan.

Adapun alasan peneliti memilih Koperasi Serba Usaha Tabungan Nasional sebagai obyek penelitian yaitu, KSU Tabungan Nasional ini telah berdiri sudah sangat lama, karena lamanya berdiri koperasi ini membuat budaya dari organisasi KSU Tabungan Nasional terbentuk sudah cukup kuat untuk mempengaruhi pola pikir dan sikap dari masing-masing karyawan koperasi sehingga dapat mempengaruhi kinerja karyawan pada generasi ke generasi. Berbeda dengan koperasi yang baru beroperasi sehingga memiliki budaya organisasi yang baru terbentuk dan kemungkinan mudah berubah-ubah. Selain itu, budaya organisasi pada KSU Tabungan Nasional digunakan sebagai budaya perusahaan yang berbasis kinerja karyawan sehingga karyawan dituntut untuk memahami dan menerapkan budaya. Berdasarkan paparan di atas maka penelitian ini bertunuan untuk mengetahui pengaruh antara budaya organisasi terhadap kinerja karyawan pada ksu tabungan nasional, singaraja.

\section{METODE}

Berikut ini adalah definisi operasional dari variabel dependen danvariabel independen, adalah sebagai berikut: Budaya Organisasi (X), Menurut Denison \& Mishra (1995) budaya organisasi adalahjawaban terhadap kuesioner dari para responden tentang bagaimana sikap-sikap,nilai-nilai, normanorma dan pengharapan-pengharapan bersama yang dimiliki oleh anggotaanggota organisasi untuk mengukur budaya organisasi digunakan empat indikator yangdikembangkan oleh Robbins (2002) yaitu. Arah: Organisasi memiliki tujuan dan arah yang jelas. Organisasi mendefinisikantujuan dan sasaran stratejik dan mengekspresikan visi masa depan, Integrasi: Tingkat sejauh mana unit-unit dalam organisasi didorong untuk bekerjadengan cara yang terkoordinasi, Adaptabilitas: Organisasi memiliki kemampuan adaptasi yang didorong oleh keinginanpelanggan. Organisasi mengambil resiko, belajar dari kesalahan dan memilikikapabilitas dan pengalaman untuk menciptakan perubahan, Dukungan manajemen: Tingkat sejauh mana para manajer memberi komunikasi yang jelas, bantuanserta dukungan terhadap bawahan mereka.

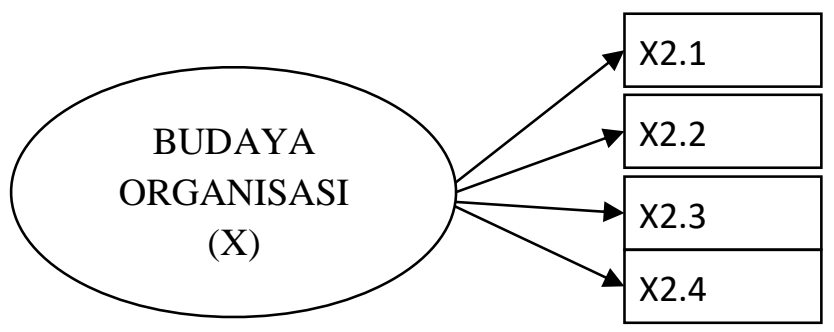




\section{Gambar 1. Indikator Variabel Budaya Organisasi \\ Sumber:Stephen P. Robbins (2002)}

\begin{tabular}{|c|c|}
\hline $\begin{array}{l}\text { Definisi operasional kinerja } \\
\text { karyawan adalah data yang diperoleh } \\
\text { dariatasan tentang hasil kinerja karyawan } \\
\text { yang ditentukan oleh beberapa indikator. } \\
\text { Dalam penelitian ini menggunakan } \\
\text { indikator yang dikembangkan oleh } \\
\text { Bernadirdan Russel serta } 1 \text { indikator } \\
\text { modifikasi yaitu: Kualitas kerja, merupakan } \\
\text { tingkatan di mana proses atau hasil } \\
\text { daripenyelesaian suatu kegiatan } \\
\text { mendekati sempurna, Kuantitas, }\end{array}$ & $\begin{array}{l}\text { ditujukan dalam suatumata uang, jumlah } \\
\text { unit, dan jumlah kegiatan yang } \\
\text { diselesaikan, Efektivitas biaya,merupakan } \\
\text { tingkatan di mana dapat memaksimalkan } \\
\text { hasilkerja dan mengurangi kerugian yang } \\
\text { timbul, Kehadiran, tingkat kehadiran } \\
\text { seorang karyawan dalam bekerja, } \\
\text { Ketepatan waktu, merupakan di mana } \\
\text { kegiatan dapat diselesaikan, atau suatu } \\
\text { hasil kerja dapat dicapai dalam waktu yang } \\
\text { telah ditetapkan. }\end{array}$ \\
\hline
\end{tabular}
merupakan produksi yang dihasilkan dapat

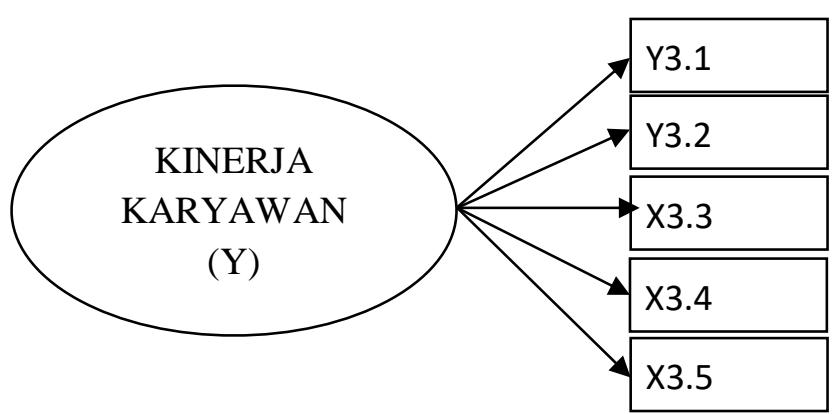

Gambar 2. Dimensi Variabel Kinerja Karyawan

Sumber: Bernadin \& Russel (2010)

Menurut Ferdinand (2006), populasi adalah gabungan dari seluruh elemen yang berbentuk peristiwa, hal atau orang yang memiliki karakteristik yang serupa yang menjadi pusat perhatian seorang peneliti, karena itu dipandang sebagai sebuah semesta penelitian.Populasi dalam penelitian ini adalah seluruh karyawan dalam Koperasi Serba Usaha Tabungan Nasional Singaraja yang berjumlah 31 karyawan.
Menurut Ferdinand (2006), sampel adalah subset dari populasi, terdiri dari beberapa anggota populasi.Metodepengambilan sampel menggunakan teknik Sampling Jenuh yaitu teknik penentuan sampel bila semua anggotapopulasi digunakan sebagai sampel. Hal ini sering dilakukan bila jumlah populasirelatif kecil. Sampel yang digunakan dalam penelitian ini adalah seluruhkaryawan di KSU Tabungan 
Nasional Singaraja yang berjumlah 31 karyawan.

Sumber data adalah segala sesuatu yang dapat memberikan informasi mengenai data.Berdasarkan sumbernya, data dibedakan menjadi dua, yaitu data primer dan data sekunder. Menurut Sekaran (2007), data primer adalah data yang diperoleh secara langsung oleh peneliti yang berkaitan dengan variabel dalam penelitian.Data primer yang digunakan dalam penelitian ini berupa data variabel budaya organisasi, dan kinerja karyawan. Menurut Sekaran (2007), data sekunder adalah data yang sudah tersedia yang berasal dari organisasi. Data sekunder yang digunakan dalam penelitian ini berupa jumlah karyawan pada KSU Tabungan Nasional Singaraja, profil KSU Tabungan Nasional Singaraja, struktur organisasi, dan masa kerja karyawan yang diperoleh dari pihak koperasi

Metode pengumpulan data dalam penelitian merupakan metode atau cara yang digunakan oleh peneliti untuk mendapatkan data dalam suatu penelitian. Metode pengumpulan data dalam penelitian ini adalah : (1) Metode pengumpulan data primer, engumpulan data ini dilakukan dengan menggunakan kuesioner dan wawancara. Kuesioner adalah sejumlah pertanyaan secara tertulis yang akan dijawaboleh responden penelitian, agar peneliti memperoleh data lapangan/empiris untukmemecahkan masalah penelitian dan menguji hipotesis yang telah ditetapkan.Data dalam penelitian ini adalah kuesioner yang disebarkan secara personalkepada seluruh karyawan KSU Tabungan Nasional Singaraja yang sesuai dengankarakteristik yang telah ditentukan. Kuesioner ini dibuat dengan menyertakan data diri responden dan menggunakan pertanyaan tertutup yang diukur dengan skala likert. Menurut Sugiyono (2004), skala likert digunakan untuk mengukur sikap, pendapat, dan persepsi seseorang atau sekelompok orang tentang fenomena sosial Skala likert berisi 5 tingkat prefensi jawaban dengan pilihan sebagai berikut : 1 = sangat tidak setuju (STS), 2 = tidak setuju (TS), 3 = kurang setuju (KS), $4=$ setuju (S), $5=$ sangat setuju (SS). Wawancara adalah cara pengumpulan data dengan menggunakan pertanyaan secara lisan kepada beberapa responden untuk memperoleh informasi yang berguna bagi penelitian. Penelitian ini menggunakan wawancara tidak terstruktur karena dapat mengajukan pertanyaan yang lebih luas, lebih terbuka.Peniliti dengan demikian dapat mengganti lebih banyak dan lebih dalam serta dapat memunculkan banyak faktor lainnya yang tidak terpikirkan pada awal wawancara (Ferdinand, 2006). (2) Metode pengumpulan data sekunder, Pengumpulan data sekunder dalam penilitian ini diperoleh dari pihak KSU Tabungan Nasional Singaraja, seperti jumlah karyawan pada KSU Tabungan Nasional Singaraja, profil KSU Tabungan Nasional Singaraja, struktur organisasi, dan masa prestasi kerja karyawan.

Dalam penelitian ini juga menggunakan uji asumsi klasik untuk mendukung keakuratan dari data yang di sajikan dimana uji asumsi klasik yang digunakan adalah uji Multikolonieritas untuk menguji apakah model regresiditemukan adanya korelasi antar variabel bebas (Variabel Independen), uji Heteroskedastisitas untuk menguji apakah dalam modelregresi terjadi ketidaksamaan variance dari residual satu pengamatankepengamatan yang lain, uji Normalitas untuk menguji apakah model regresi, variabelpengganggu atau residual memiliki distribusi normal, dan Analisis regresi linier sederhana didasarkan pada hubungan fungsional ataupun kasual suatu variabel independen dengan satu variabel dependen.

\section{HASIL DAN PEMBAHASAN Hasil}

Uji Multikolonieritas bertujuan untuk menguji apakah model regresi ditemukan adanya korelasi antar variabel bebas (Variabel Independen). Model regresi yang baik seharusnya tidak terjadi korelasi diantara variabel independen. Untuk mengetahui ada atau tidaknya multikolinieritas maka dapat dilihat dari nilai Tolerance dan Varians Inflation Faktor (VIF).Kedua ukuran ini menunjukkan setiap variabel independen lainnya. Nilai cut off yang digunakan untuk menunjukkan 
multikolinieritas adalah tolerance $>0,1$ dan nilai VIF $<10$. Bila angka VIF melebihi 10 dan nilai Tolerance $<0,1$ berarti terjadi multikolinieritas (Ghozali, 2013). Hasil uji multikolinearitas disajikan pada Tabel 1 berikut:

Tabel 1. Hasil Uji Multikolinearitas

\begin{tabular}{cccc}
\hline No. & Variabel & Tolerance & VIF \\
\hline 1 & Budaya Organsisasi $(\mathrm{X})$ & 1,000 & 1,000 \\
\hline
\end{tabular}

Sumber: Data Primer Diolah, 2018

Berdasarkan Tabel 1 dapat dilihat bahwa nilai tolerance melebihi 0,1 dan nilai VIF kurang dari 10. Hal ini berarti data telah lolos uji multikolinearitas. Uji Heteroskedastisitas bertujuan untuk menguji apakah dalam model regresi terjadi ketidaksamaan variance dari residual satu pengamatan kepengamatan yang lain. Jika variance dari residual 1 pengamatan ke pengamatan lain tetap maka disebut homoskedastisitas dan jika berbeda disebut heteroskedastisitas. Cara yang digunakan untuk mendeteksi heteroskesdatisitas adalah menggunakan analisis grafik scatter plot. Jika menggunakan analisis grafik scatter plot, dikatakan tidak terjadi heteroskedastisitas apabila tidak ada pola yang jelas serta titiktitik menyebar diatas dan dibawah angka 0 pada sumbu Y. Sebaliknya, jika ada pola tertentu, seperti titik-titik yang ada membentuk pola tertentu yang teratur (seperti, bergelombang, melebar, kemudian menyempit), maka menunjukkan telah terjadi heteroskedastisitas. Hasil uji heteroskedastisitas dalam penelitian ini dapat dilihat pada Gambar 3 berikut:

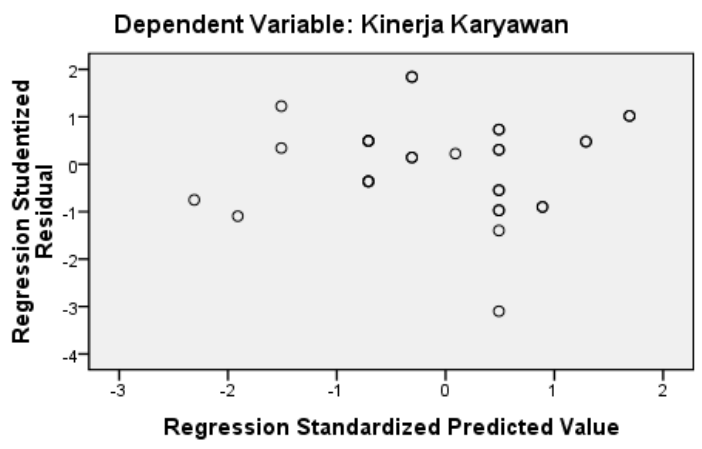

\section{Gambar 3. Hasil Uji Heteroskedastisitas Dengan Analisis Grafik Scatterplot}

Berdasarkan gambar 3 dapat dilihat bahwa tidak terdapat pola yang jelas serta titik-titik menyebar diatas dan dibawah angka 0 pada sumbu $Y$. Dengan demikian dapat disimpulkan bahwa tidak terjadi gejala heteroskedastisitas dalam penelitian ini maka asumsi heteroskedastisitas terpenuhi.
Uji normalitas bertujuan untuk menguji apakah model regresi, variabel pengganggu atau residual memiliki distribusi normal. Analisis grafik sebenarnya cara termudah untuk melihat normalitas residual adalah dengan melihat grafik histogram yang membandingkan antara data observasi dengan distribusi 
yang mendekati distribusi normal. Distribusi normal akan membentuk satu garis lurus diagonal dan ploting data residual akan dibandingkan dengan garis diagonal. Dengan kata lain, data dikatakan normal jika data menyebar disekitar garis diagonal dan mengikuti arah diagonal atau grafik histogramnya. Hasil uji normalitas dalam penelitian ini dapat dilihat pada Gambar 4 berikut:

\section{Normal P-P Plot of Regression Standardized Residual}

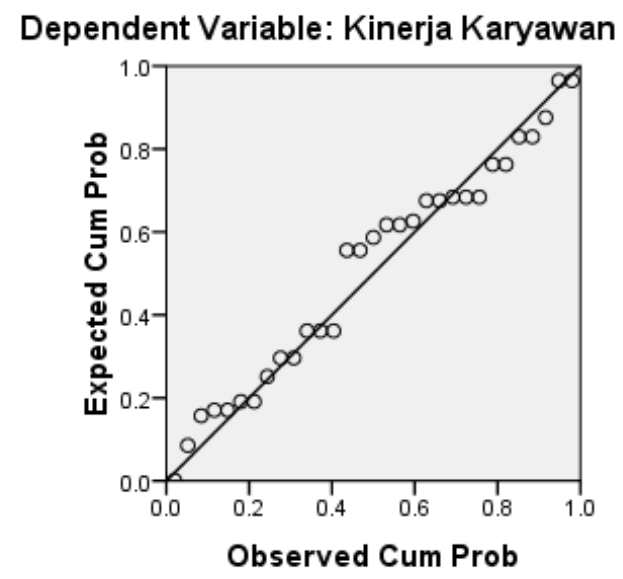

\section{Gambar 4. Hasil Uji Normalitas Dengan Normal P-Plot}

Berdasarkan Gambar 4 dapat dilihat bahwa data menyebar disekitar garis diagonal dan mengikuti arah diagonal atau grafik histogramnya. Jadi, dapat disimpulkan bahwa asumsi normalitas sudah terpenuhi. Dengan kata lain data sudah berdistribusi normal.

Analisis regresi linier sederhana didasarkan pada hubungan fungsional ataupun kasual suatu variabel independen dengan satu variabel dependen. Sehingga dalam hal ini analisis regresi linier sederhana bertujuan untuk mengetahui hubungan fungsional antara budaya organisasi terhadap kinerja karyawan. Hasil analisis regresi linier sederhana dapat dilihat pada Tabel 2 berikut:

Tabel 2. Analisis Regresi Linier Sederhana

Coefficients $^{\mathrm{a}}$

\begin{tabular}{|c|c|c|c|c|c|c|}
\hline \multirow{2}{*}{\multicolumn{2}{|c|}{ Model }} & \multicolumn{2}{|c|}{$\begin{array}{l}\text { Unstandardized } \\
\text { Coefficients }\end{array}$} & \multirow{2}{*}{$\begin{array}{c}\text { Standardized } \\
\text { Coefficients }\end{array}$} & \multirow[b]{2}{*}{$t$} & \multirow[b]{2}{*}{ Sig. } \\
\hline & & B & Std. Error & & & \\
\hline \multirow[t]{2}{*}{1} & (Constant) & 14,893 & 5,937 & & 2,509 & 0,018 \\
\hline & $\begin{array}{l}\text { Budaya } \\
\text { Organisasi }\end{array}$ & 0,811 & 0,175 & 0,652 & 4,627 & 0,000 \\
\hline
\end{tabular}

a. Dependent Variable: Kinerja Karyawan

Sumber: Data Primer Diolah, 2018

Berdasarkan tabel 2 diatas, diperoleh persamaan regresi $Y=14,893+0,811(X)$
Dari persamaan diatas dapat diinterpretasikan sebagai berikut: (a) Nilai 
constant sebesar 14,893 berarti bahwa apabila variabel Budaya Organisasi dianggap kosntan, maka rata-rata Kinerja Karyawan sebesar 14,893. (b) Nilai X adalah sebesar 0,811 , berarti bahwa apabila Budaya Organisasi (X) mengalami peningkatan 1 tingkat, maka Kinerja Karyawan akan meningkat sebesar 0,811 tingkatan dengan asumsi variabel lainnya dianggap konstan.

Uji statistik t pada dasarnya menunjukkanseberapa jauh pengaruh satu variabel penjelas atau variabel independen secaraindividual dalam menerangkan variasi variabel dependen. Sehingga dalam hal ini uji $t$ dilakukan untuk mengetahui pengaruh variabel Budaya
Organisasi terhadap Kinerja Karyawan pada KSU Tabungan Nasional, Singaraja. Dalam pengujian ini, thitung akan dibandingkan dengan $t_{\text {tabel }}$ dengan taraf signifikansi $\alpha=0,05$. Taraf nyata atau level of significant (a) ditentukan sebesar 0,05 atau $5 \%$ dan $\mathrm{df}=(\mathrm{n}-\mathrm{k})$ untuk menentukan $t_{\text {tabel. }}$. Nilai $\mathrm{df}=(31-2)$ dengan taraf signifikasi 0,05 maka diperoleh $t_{\text {tabel }}$ sebesar 2,045. Apabila nilai t hasil hitung lebih tinggi dibandingkannilai tabel, maka dapat dinyatakan bahwa suatu variabel independen secara parsialatau individu mempengaruhi variabel dependen. Hasil uji t (uji parsial) dapat dilihat pada Tabel 3 berikut:

Tabel 3. Hasil Uji t (Uji Parsial)

\begin{tabular}{|c|c|c|c|c|c|c|}
\hline \multirow{2}{*}{\multicolumn{2}{|c|}{ Model }} & \multicolumn{2}{|c|}{$\begin{array}{l}\text { Unstandardized } \\
\text { Coefficients }\end{array}$} & \multirow{2}{*}{$\begin{array}{c}\text { Standardized } \\
\text { Coefficients }\end{array}$} & \multirow[b]{2}{*}{$t$} & \multirow[b]{2}{*}{ Sig. } \\
\hline & & $B$ & Std. Error & & & \\
\hline \multirow[t]{2}{*}{1} & (Constant) & 14,893 & 5,937 & & 2,509 & 0,018 \\
\hline & $\begin{array}{l}\text { Budaya } \\
\text { Organisasi }\end{array}$ & 0,811 & 0,175 & 0,652 & 4,627 & 0,000 \\
\hline
\end{tabular}

a. Dependent Variable: Kinerja Karyawan

Sumber: Data Primer Diolah, 2018

Berdasarkan Tabel 3 dapat dilihat bahwa hasil uji secara individu terhadap variabel Budaya Organisasi (X) diperoleh nilai thitung sebesar 4,627 dannilai signifikansi sebesar 0,000. Hal ini menunjukkan bahwa nilai thitung sebesar 4,627 lebih besar dari tabel sebesar 2,045. Sehingga dapat dikatakan bahwa Budaya Organisasi berpengaruh positif terhadap Kinerja Karyawan. Nilai signifikansi sebesar 0,000 lebih kecil dari 0,05 menunjukkan bahwa adanya pengaruh signifikan dari Budaya Organisasi terhadap Kinerja Karyawan. Sehingga dalam hal ini dapat disimpulkan bahwa hipotesis diterima, yaitu Budaya Organisasi berpengaruh positif terhadap Kinerja Karyawan. Menurut Imam Ghozali (2013) koefisien determinasi $(\mathrm{R})$ pada intinyamengukur seberapa jauh kemampuan model dalam menerangkan variasi variabeldependen. Sehingga dalam hal ini dihitunglah koefisien determinasi dengan tujuan untuk mengukur seberapa jauh Budaya Organisasi dalam menerangkan Kinerja Karyawan. Hasil uji dapat dilihat pada Tabel 4. berikut:

\section{Tabel 4. Hasil Koefisien Determinasi Model Summary ${ }^{b}$}




\begin{tabular}{lrrrrr}
\hline $\begin{array}{l}\text { Mode } \\
\mathrm{I}\end{array}$ & $\mathrm{R}$ & $\mathrm{R}$ Square & $\begin{array}{r}\text { Adjusted } \\
\mathrm{R} \text { Square }\end{array}$ & $\begin{array}{r}\text { Std. Error of } \\
\text { the Estimate }\end{array}$ & Durbin-Watson \\
\hline 1 & $0,652^{\mathrm{a}}$ & 0,425 & 0,405 & 2,400 & 2,030 \\
\hline
\end{tabular}

a. Predictors: (Constant), Budaya Organisasi

b. Dependent Variable: Kinerja Karyawan

Sumber: Data Primer Diolah, 2018

Berdasarkan Tabel 4 dapat diketahui bahwa $R$ Square $=0,425$ yang berarti variabel Kinerja Karyawan dapat dijelaskan oleh Budaya Organisasi sebesar $42,5 \%$. Sedangkan sisanya sebesar $57,5 \%$ dijelaskan oleh variabel lain diluar variabel penelitian ini.

\section{Pembahasan}

Menurut Wibowo (2013), budaya organisasi adalah filosofi dasar organisasi yang memuat keyakinan, norma-norma, dan nilai-nilai bersama yang menjadi karakteristik inti tentang bagaimana cara melakukan sesuatu dalam organiasasi. Keyakinan, norma-norma, dan nilai-nilai tersebut menjadi pegangan semua sumber daya manusia dalam organisasi dalam melaksanakan kinerjanya.

Berdasarkan hasil pengujian hipotesis, Budaya Organisasi (X) diperoleh nilai thitung sebesar 4,627 dannilai signifikansi sebesar 0,000 . Hal ini menunjukkan bahwa nilai $t_{\text {hitung }}$ sebesar 4,627 lebih besar dari $t_{\text {tabel }}$ sebesar 2,045.Nilai signifikansi sebesar 0,000 lebih kecil dari 0,05 menunjukkan bahwa adanya pengaruh signifikan dari Budaya Organisasi terhadap Kinerja Karyawan (Y). Dengan kata lain, Budaya Organisasi $(X)$ berpengaruh positif dan signifikan terhadap Kinerja Karyawan (Y). Hasil penelitian ini sejalan dengan hasil penelitian Ritchie (2000), Koesmono (2005), Ojo (2009), Shahzad (2013, dan Kumar (2013) yang menyatakan bahwa Budaya Organisasi berpengaruh positif terhadap Kinerja Karyawan.

Budaya organisasi yang kuat akan mempengaruhi pola pikir dan tindakan karyawan dalam menyelesaikan tugastugasnya. Perusahaan yang memiliki budaya yang kuat akan mampu meningkatkan kinerja karyawannya, menumbuhkan semangat kebersamaan dikalangan para anggotanya, meningkatkan rasa nyaman dan royal terhadap perusahaan serta mampu membesarkan keuntungan perusahaan. Begitupula yang terjadi pada KSU Tabungan Nasional, Singaraja, KSU Tabungan Nasional, Singaraja memiliki budaya organisasi yang kuat sehingga mampu meningkatkan kinerja karyawannya.

\section{SIMPULAN DAN SARAN Simpulan}

Berdasarkan hasil penelitian yang dilakukan pada Koperasi Serba Usaha Tabungan Nasional Singaraja maka dapat disimpulkan bahwa Hasil analisis menunjukkan bahwa variabel Budaya Organisasi $(X)$ mempunyai pengaruh yang cukup signifikan terhadap variabel kinerja karyawan dengan nilai signifikan sebesar 0,000 (pada tingkat kesalahan 5\%), sehingga dapat disimpulkan bahwa Budaya Organisasi (X) mempunyai pengaruh yang signifkan terhadap Kinerja Karyawan (Y) pada Koperasi Serba Usaha Tabungan Nasional Singaraja.

\section{Saran}

Berdasarkan hasil penelitian yang dilakukan, penulis mencoba memberikan saran-saran untuk diperhatikan bagi pihakpihak yang terkait di Koperasi Serba Usaha Tabungan Nasional Singaraja, adapun saran-saran yang penulis berikan adalah. Budaya Organisasi terhadapat Kinerja Karyawan pada KSU Tabungan Nasional Singaraja sudah cukup baik, sehingga pimpinan di KSU Tabungan Nasional perlu

Made Ary Meitriana I Page 43 dari 51 
mempertahankannya dengan membangun iklim kerja yang lebih mendukung budaya organisasi untuk mempengaruhi karyawan dalam meningkatkan kinerjanya. Pimpinan di KSU Tabungan Nasional perlu merumuskan budaya organisasi dengan jelas, yaitu dengan menuangkan dalam suatu bentuk pedoman tingkah laku secara tertulis agar dapat mempersatukan kesepahaman para karyawan dalam bekerja.

\section{Daftar Pustaka}

Augusty, Ferdinand. 2006. Metode Penelitian Manajemen: Pedoman Penelitian untuk skripsi, Tesis dan Disertai IImu Manajemen. Semarang: Universitas Diponegoro

Bernardin, H.John and Russel. 2010. Human Resource Management. New York: McGraw-Hill

Darmawan, Ali Mufi Hendra. 2014. Pengaruh Budaya Organisasi Terhadap Kinerja Karyawan. Skripsi. Fakultas Ekonomi Dan Bisnis, Universitas Muhammadiyah Malang

Denison, D.R. and Mishra, A.K. 1995, Toward a theory of organizational culture andeffectiveness, Organization Science, Vol. 6 No. 2, pp. 204-23

Ghozali, Imam. 2013. Aplikasi Analisis Multivariate dengan Program IBM SPSS 21 Update PLS Regresi. Semarang: Badan Penerbit Universitas Diponegoro

Kurniawan, Ahmad. 2017. Pengaruh Gaya Kepemimpinan Dan Budaya Organisasi Terhadap Kinerja Melalui Kepuasan Kerja Karyawan. Skripsi. Fakultas IImu Sosial Dan IImu Politik Universitas Lampung. Bandar Lampung

Robbins, P. Stephen. 2002. Perilaku Organisasi: Konsep Kontroversi, Aplikasi. Jilid I Terjemahan. PT. Indeks Kelompok Gramedia. Jakarta
Sekaran, Uma. 2007. Metodologi Penelitian untuk Bisnis. Edisi 4.Buku 2. Jakarta: Salemba Empat

Sugiyono. 2004. Metode Penelitian. Bandung: Alfabeta

Tika, H. Moh. Pabundu. 2006. Budaya Organisasi dan Peningkatan Kinerja Perusahaan. Bumi Aksara

Wibowo, SE, M. Phil, Prof, 2010. Budaya Organisasi : Sebuah Kebutuhan untuk Meningkatkan Kinerja Jangka Panjang. Edisi Pertama. PT. Raja Grafindo Persada. Jakarta 